\title{
Junction Plakoglobin
}

National Cancer Institute

\section{Source}

National Cancer Institute. Junction Plakoglobin. NCI Thesaurus. Code C17524.

Junction plakog lobin (744 aa, $\sim 82 \mathrm{kDa}$ ) is encoded by the human JUP gene. This protein is involved in adherens junction assembly. 